\title{
Does Valproate Treatment in Childhood Epilepsy Affect Nutritional Status and Biochemical Parameters?
}

\author{
Çocukluk Çağı Epilepsisinde Valproat Tedavisi Beslenme Durumunu \\ ve Biyokimyasal Parametreleri Etkiler mi?
}

\author{
Esra KOSELER BEYAZ, Sinem BAYRAM
}

Department of Nutrition and Dietetics, Baskent University, Faculty of Health Sciences, Ankara, Turkey

\begin{abstract}
Objective: Valproate (VPA) is widely prescribed for the treatment of various neurological and neuropsychiatric disorders. This study aimed to determine the effect of VPA therapy, which was thought to have weight gain effect on nutritional status and some biochemical factors in children with epilepsy.

Material and Methods: The study included 30 children and adolescents who received VPA monotherapy because of the diagnosis of epilepsy. Selected biochemical parameters before and 12 months after VPA treatment were recorded retrospectively from the patient files. VPA dose ranges from $11-40 \mathrm{mg} / \mathrm{kg} /$ day. VPA plasma levels were maintained within the therapeutic limits throughout the study. The anthropometric measurements of the patients were recorded in the WHO Anthro program for children aged 1-5 years and the WHO Anthro-Plus program for children aged 5-18 years.

Results: The epilepsy age of the patients was determined as $48.85 \pm 38.16$ months; and they have been receiving VPA therapy at a dose of $25.00 \pm 10.75 \mathrm{mg} / \mathrm{kg} /$ day for $18.95 \pm 6.02$ months. While no difference was found in terms of hunger visual analogue scale (VAS) scores before and after treatment, VAS scores of appetite increased and satiety decreased $(p<0.05)$. BMI-SDSs, fasting insulin $(\mu \mathrm{lU} / \mathrm{mL}), \mathrm{HDL}$ cholesterol $(\mathrm{mg} / \mathrm{dL})$ and triglyceride $(\mathrm{mg} / \mathrm{dL})$ levels increased after VPA treatment $(p<0.05)$.
\end{abstract}

Conclusion: As a result, it has been determined that VPA treatment can decrease satiety and increase appetite, cause weight gain, and affect some biochemical parameters negatively such as insulin and blood lipids.

Key Words: Epilepsy, Hunger, Nutritional status, Obesity

Öz

Amaç: Valproik asit, çeșitli nörolojik ve nöropsikiyatrik bozuklukların tedavisi için yaygın olarak reçete edilmektedir. Bu çalışmada epilepsili çocuklarda ağırlık artışına etkisi olduğu düşünülen valproik asit tedavisinin beslenme durumu ve bazı biyokimyasal faktörler üzerine etkisinin belirlenmesi amaçlanmıştır.

Gereç ve Yöntemler: Çalışmaya epilepsi tanısı ile valproik asit monoterapisi alan 30 çocuk ve ergen dahil edildi. VPA tedavisinden önce ve 12 ay sonra seçilen biyokimyasal parametreler hasta dosyalarından geriye dönük olarak kaydedildi. Etken madde dozu 11-40 mg/kg/gün arasında değişmektedir. VPA plazma seviyeleri, çalsşma boyunca terapötik sınılar içinde tutulmuştur. Hastaların antropometrik ölçümleri 1-5 yaş arası çocuklar için WHO Anthro programı ve 5-18 yaş arası çocuklar için WHO Anthro-Plus programı ile hesaplanmıştır.

Bulgular: Hastaların epilepsiyașı $48.85 \pm 38.16$ ay olarak belirlenmiş olup hastalar ortalama $18.95 \pm 6.02$ aydır $25.00 \pm 10.75$ $\mathrm{mg} / \mathrm{kg} / \mathrm{gün}$ VPA tedavisi almaktadırlar. Tedavi öncesi ve sonrası açlık VAS skorları açısından fark bulunmazken, iştah

(1) 0000-0001-7713-7871: KOSELER BEYAZE 0000-0003-1569-7747 : BAYRAM S
Conflict of Interest / Çıkar Çatışması: On behalf of all authors, the corresponding author states that there is no conflict of interest.

Ethics Committee Approval / Etik Kurul Onayr: This study was conducted in accordance with the Helsinki Declaration Principles. This study was approved by Baskent University Institutional Review Board (Project no: KA16/120) and supported by Baskent University Research Fund.

Contribution of the Authors / Yazarların katkısı: KOSELER BEYAZ E: Constructing the hypothesis or idea of research and/or article, Taking responsibility in patient follow-up, collection of relevant biological materials, data management and reporting, execution of the experiments, Taking responsibility in necessary literature review for the study, Taking responsibility in the writing of the whole or important parts of the study, Reviewing the article before submission scientifically besides spelling and grammar. BAYRAM S: Constructing the hypothesis or idea of research and/or article, Planning methodology to reach the Conclusions, Organizing, supervising the course of progress and taking the responsibility of the research/study, Taking responsibility in patient follow-up, collection of relevant biological materials, data management and reporting, execution of the experiments, Taking responsibility in logical interpretation and conclusion of the results, Taking responsibility in the writing of the whole or important parts of the study.

How to cite / Atıf yazım şekli : Koseler Beyaz E and Bayram S. Does Valproate Treatment in Childhood Epilepsy Affect Nutritional Status and Biochemical Parameters?. Turkish J Pediatr Dis 2022;16:225-229.
Correspondence Address / Yazıșma Adresi:

\section{Sinem BAYRAM}

Department of Nutrition and Dietetics,

Baskent University, Faculty of Health Sciences, Ankara, Turkey, Ankara, Turkey

E-posta: metins@baskent.edu.tr
Received / Geliş tarihi : :26.11.2021 Accepted / Kabul tarihi : 12.01.2022 Online published Elektronik yayın tarihi

DOI: $10.12956 /$ tchd.1028406 
görsel analog skalası (VAS) skoru artmış, tokluk VAS skoru ise azalmıştır $(p<0.05)$. Tedavi sonrası hastaların yaşa göre BKI z skorları, açlık insülini ( $\mu \mathrm{lU} / \mathrm{mL})$, HDL kolesterol (mg/dL) ve trigliserit $(\mathrm{mg} / \mathrm{dL})$ seviyelerinin arttığı saptanmıştır $(\mathrm{p}<0.05)$.

Sonuç: Sonuç olarak VPA tedavisinin tokluğu azaltıp iştahı artırabileceği, ağılık kazanımına katkıda bulunabileceği, insülin ve kan lipidleri gibi bazı biyokimyasal parametreleri olumsuz etkileyebileceği belirlenmiştir.

Anahtar Sözcükler: Epilepsi, Açlık, Beslenme durumu, Obezite

\section{INTRODUCTION}

Epilepsy is one of the most common neurological diseases affecting people of all ages, races, social classes and geographic regions. Epilepsy is a brain disease characterized by a persistent predisposition to seizures and the neurobiological, cognitive, psychological and social consequences of seizure recurrences (1). Anti-epileptic drugs are the primary treatment method, which are used to provide seizure control without causing side effects that may affect quality of life. Seizure remission is likely to reduce morbidity and the risk of premature death. In addition to the efficacy of anti-epileptics, age, gender, childbearing potential, comorbidities, tolerability, seizure type, and epileptic status may affect drug selection due to their role in body weight fluctuations and biochemical parameters (2).

One of the antiepileptic drugs commonly used in the treatment of epilepsy is VPA. VPA is a selective inhibitor of histone deacetylase, which plays important roles in epigenetic regulation. While VPA is a widely prescribed drug for the treatment of various neurological and neuropsychiatric disorders, important side effects of VPA are weight gain and metabolic disturbances in patients (3). A recent study stated $10-70 \%$ of children using VPA may have side effects related to body weight (4). One study found that $40.4 \%$ of patients treated with VPA gained more than $10 \%$ of their total body weight, while only $8 \%$ of patients treated with other antiepileptics (5). In another study, in approximately $17 \%$ of patients treated with VPA monotherapy has been reported to have obesity (6).

Although the mechanisms of VPA increasing body weight can not be clearly explained, especially in children; potential mechanisms are associated with increased insulin and leptin levels (7). In addition, dysregulation of the hypothalamic system which is affected by adipokine levels, hyperinsulinemia, insulin resistance and genetic predisposition are the other potential mechanisms. The expression of adipokines, that encode neuropeptides such as resistin and leptin, which are involved in the development of insulin resistance and obesity, also increase with VPA theraphy (8). It has been reported that VPA increases leptin, insulin, neuropeptide-y (NPY), and fasting insulin-glucose ratio, while reducing beta-oxidation of lipids due to carnitine deprivation. It is known that due to the lipogenic effect of insulin, it stimulates triacylglycerol and fatty acid synthesis, suppresses fatty acid oxidation, and leptin acts as an antagonist to insulin with its lipolytic effect. However, this balance is important in maintaining weight, it is thought that VPA theraphy increases energy balance and appetite by increasing NPY levels and through GABAergic agonistic effect on hypothalamus. Especially in the early stages of VPA theraphy, the increase in ghrelin levels activates the neuropeptide $Y$ pathway, which stimulates appetite and food intake (9).

In this study, we aimed to determine the effect of VPA therapy, which was thought to have weight gain effect on nutritional status and some biochemical factors in children with epilepsy.

\section{MATERIAL and METODS}

This study was performed in Pediatric Neurology Clinic of Ankara Gulhane Education and Research Hospital between October 2016 and January 2019. The study included 30 children and adolescents who received VPA monotherapy because of the diagnosis of epilepsy. The inclusion criteria of the study group were; being in childhood (age between 5-18 years) taking only VPA therapy for at least 1 year, no diet restriction and feeding difficulty. Children who have been using VPA for more than 3 years, children with metabolic/endocrine diseases, genetic disorders affecting growth, degenerative neurological diseases, and those using multiple antiepileptics were not included in the study. This study was approved by Baskent University Institutional Review Board (Project no: KA16/120) and supported by Baskent University Research Fund.

The caregivers of the child were asked to keep a seizure diary, which included the type and frequency of seizures. The questionnaire form was applied by face-to-face interview method in order to determine the demographics, anthropometric status and disease information. Patients were asked to make a checklist of food groups to evaluate their consumption before and after VPA treatment. Visual analog scales (VAS, 0-10 cm) used to assess appetite, satiety and hunger. Patients were asked to mark for both pre and post VPA treatment. The changes in the consumption of some food groups of the patients participating in the study were also questioned in the period before and after the VPA treatment.

Selected biochemical parameters before and 12 months after VPA treatment were recorded retrospectively from the patient files. VPA dose ranges from $11-40 \mathrm{mg} / \mathrm{kg} /$ day. VPA plasma levels were maintained within the therapeutic limits throughout the study.

Body weight $(\mathrm{kg})$ and height $(\mathrm{cm})$ of children before initiation and after 12 months VPA treatment period were obtained from patient files. Only the results of patients who had blood 
samples taken after 12 hours of fasting in the morning were included. Analyses of the selected biochemical parameters such as fasting blood glucose (mg/dL), fasting insulin ( $\mu \mathrm{lU} /$ $\mathrm{mL})$, triglyceride $(\mathrm{mg} / \mathrm{dL}), \mathrm{HDL}(\mathrm{mg} / \mathrm{dL}), \mathrm{LDL}(\mathrm{mg} / \mathrm{dL})$ were performed.

The anthropometric measurements of the patients were recorded in the WHO Anthro program for children aged 1-5 years and the WHO Anthro-Plus program for children aged 5-18 years (10).

\section{Statistical analysis}

The data in the study were analyzed in the SPSS-21 statistics program. While mean and standard deviation values are given for quantitative variables, frequency and percentage values are given for categorical measures. "Wilcoxon t-test" was used to test the mean differences between pre and post VPA treatment for selected variables. All analyzes were interpreted at the 95\% confidence level.

\section{RESULTS}

A total of 30 patients with a mean age of $8.77 \pm 4.81$ years participated in the study. The epilepsy age of the patients was determined as $48.85 \pm 38.16$ months; and they have been receiving VPA therapy at a dose of $25.00 \pm 10.75 \mathrm{mg} / \mathrm{kg} /$ day for $18.95 \pm 6.02$ months (Table I).

The hunger, satiety and appetite VAS scores of the patients participating in the study before and after VPA treatment are given in Table II. While no difference was found in terms of hunger VAS scores before and after treatment, it was found

\section{Table I: Patient demographics}

\begin{tabular}{l|c}
\hline & $\begin{array}{c}\text { Children with epilepsy } \\
\text { (n:30) }\end{array}$ \\
\hline Gender & Girls: \%45 \\
Family history of epilepsy & Yes: \%30 \\
Seizure type & Idiopathic: \%65 \\
\hline & $\mathbf{X} \pm \mathbf{S D}$ \\
\hline Birth weight (g) & $3.23 \pm 0.72$ \\
\hline Age (year) & $8.77 \pm 4.81$ \\
\hline Epilepsy age (months) & $48.85 \pm 38.16$ \\
\hline Duration of VPA therapy (months) & $18.95 \pm 6.02$ \\
\hline VPA dose (mg/kg) & $25.00 \pm 10.75$ \\
\hline
\end{tabular}

\begin{tabular}{|c|c|c|c|}
\hline & Pre-VAP & Post-VAP & $p$ \\
\hline Hunger & $6.18 \pm 2.17$ & $6.45 \pm 2.63$ & 0.542 \\
\hline Satiety & $7.42 \pm 3.58$ & $5.94 \pm 1.59$ & $0.039^{*}$ \\
\hline Appetite & $5.32 \pm 2.34$ & $6.50 \pm 2.45$ & $0.017^{\star}$ \\
\hline
\end{tabular}

$p<0.05, \boldsymbol{p}:$ Wilcoxon paired test

\begin{tabular}{|c|c|c|c|}
\hline & Pre-VAP & Post-VAP & $p$ \\
\hline BMI-SDs & $0.94 \pm 0.46$ & $1.39 \pm 0.56$ & $0.000^{*}$ \\
\hline Weight-SDs & $0.88 \pm 0.62$ & $1.23 \pm 0.49$ & $0.003^{*}$ \\
\hline Height-SDs & $0.68 \pm 1.03$ & $0.65 \pm 0.96$ & 0.344 \\
\hline
\end{tabular}

p<0.05, BMI-SDs: body mass index standard deviations, VPA: valproate, p: Wilcoxon paired test

Table IV: Biochemical parameters of patients before and after VPA treatment.

\begin{tabular}{|l|c|c|c|}
\hline & Pre-VAP & Post-VAP & p \\
\hline Fasting blood glucose $(\mathrm{mg} / \mathrm{dL})$ & $88.5 \pm 7.8$ & $91.2 \pm 20.4$ & 0.064 \\
\hline Fasting insulin $(\mu \mathrm{l} \mathrm{U} / \mathrm{mL})$ & $10.0 \pm 7.9$ & $12.1 \pm 9.4$ & 0.026 \\
\hline Triglycerid $(\mathrm{mg} / \mathrm{dL})$ & $61.7 \pm 24.8$ & $71.3 \pm 26.6$ & 0.001 \\
\hline HDL $(\mathrm{mg} / \mathrm{dL})$ & $54.9 \pm 6.3$ & $55.5 \pm 3.4$ & 0.032 \\
\hline LDL $(\mathrm{mg} / \mathrm{dL})$ & $83.0 \pm 9.9$ & $84.2 \pm 27.4$ & 0.052 \\
\hline
\end{tabular}

$p<0.05, \boldsymbol{p}:$ Wilcoxon paired test

that VAS scores for appetite increased and satiety decreased $(p<0.05)$.

The BMI, weight and height standard deviation scores of the patients participating in the study before and after VPA treatment are given in Table III. It was determined that the BMI-SDS of the patients increased after treatment $(p<0.05)$ (Table III). Fasting insulin, HDL cholesterol and triglyceride levels increased after VPA treatment $(p<0.05)$ (Table IV).

\section{DISCUSSION}

VPA is one of the most widely prescribed anti-epileptic drugs worldwide. It is stated that long-term treatment with VPA is associated with risks such as weight gain, hyperinsulinemia, metabolic syndrome, and cardiovascular disease (11). Factors such as birth and head trauma, age, genetic predisposition, infections, and vascular diseases may facilitate the development of epilepsy. It has been determined that infants with low birth weight are also at higher risk of epilepsy later in life $(12,13)$. The birth weights of the children participating in this study were found to be normal.

One of the known side effects of VPA, which is used as an anticonvulsant in the treatment of bipolar disorders, migraine and epilepsy, is weight gain. Weight gain has been reported in $57 \%$ of adults and $58 \%$ of children and adolescents treated with VPA. In our study, 12 month VPA therapy caused weight gain in epileptic children. The BMI-SDSs of the patients increased $(1.39 \pm 0.56)$ after VPA treatment $(0.94 \pm 0.46)(p<0.05)$. Although the mechanism of VPA increasing body weight is not clearly understood; it is stated that changes in energy intake or expenditure of VPA may result from changes in biological mechanisms, including hormone levels. In vitro studies show 
that VPA initiates pancreatic insulin secretion, which can increase appetite and energy storage and result in weight gain. VPA treatment has been found to increase postprandial insulin levels (14).

One study found that participants treated with VPA had higher serum insulin levels. They concluded that hyperinsulinemia and possibly insulin resistance contribute to weight gain (15). Chronic VPA treatment causes an increase in pancreatic insulin secretion; and it can be predicted that this increment change appetite and energy storage which associated with weight gain (16).

In a study conducted with 35 children aged 3-15 years, body weight, BMl percentiles of the participants increased significantly at the end of the 6th month compared to baseline (17). In a study of 60 prepubertal children with a mean age of 5.60+1.95 years who received VPA therapy for at least one year, BMI and BMl for age standard deviations were found to be higher in children who received VPA $(p<0.05)(18)$. Wirrell conducted a study in adolescents receiving VPA therapy for a minimum of 2 months and mild-to-moderate weight gain was observed in 58\% of the 43 subjects treated with VPA (19).

Long-term anti-epileptic therapy may trigger the atherosclerotic process by causing deterioration in endothelium and lipoprotein metabolism and therefore increase in homocysteine levels (20). We found that the fasting blood glucose, fasting insulin, triglyceride and HDL cholesterol levels of the children participating in our study increased after the VPA treatment compared to baseline ( $\mathrm{p}>0.05)$.

After 3.1 years of follow-up of 87 children receiving VPA therapy with a mean age of $4.8 \pm 0.8$ years, the mean BMISDS scores increased $(p<0.05)$; in terms of BMl classes the proportion of overweight children was $6.9 \%$ at the baseline, it was $16 \%$ at the end of the study. There was no significant change in serum fasting glucose, cholesterol and triglyceride levels (21). According to Abaci et al. after 12 months of VPA therapy, total cholesterol and LDL cholesterol levels increased significantly in children; no significant change was observed in triglyceride and HDL cholesterol levels (22). In another study, serum triglyceride concentrations increased and serum HDL cholesterol decreased with VPA therapy (23). Elevated triglycerides are observed along with HDL-cholesterol levels in patients treated with VPA (24). A randomized controlled trial, it was determined that triglyceride levels were higher and HDL cholesterol levels were significantly lower in the VPA group compared to the control group (25). There are also studies have contradictory results that VPA therapy has no effect on plasma total cholesterol, HDL cholesterol, LDL cholesterol and triglycerides $(26,27)$.

Although the effect of VPA treatment on nutritional status was tried to be examined, nutritional status could only be evaluated by anthropometric measurements and appetite based on participant's VAS scores declaration are the limitations of our study. The strength of the study is to keep the duration of VPA treatment as minimum 1 and maximum 3 years, since the effect of VPA on body weight will not be seen clearly enough in the short term and its long-term use may include other confounding factors. The selection of the patient age group as 5-18 years due to the effect of the growth and development process in infancy is another strength of the study. In future studies, it should be aimed to develop a guideline that includes medical nutrition therapy by determining the dietary intake of patients receiving VPA therapy and evaluating factors related to age, gender, and growth.

As a result, it has been determined that VPA treatment can decrease satiety and increase appetite, cause weight gain, and affect some biochemical parameters negatively such as insulin and blood lipids. It should be aimed to prevent or reduce excessive weight gain, which is thought to cause various reproductive endocrine disorders in children receiving VPA treatment. A dietitian specialized in pediatric neurology should be included in the multidisciplinary team in patients receiving VPA treatment.

\section{REFERENCES}

1. Beghi E. The epidemiology of epilepsy. Neuroepidemiology 2020;54:185-91.

2. Thijs RD, Surges R, O'Brien TJ, Sander JW. Epilepsy in adults. Lancet 2019;393: 689-701.

3. Zhang $H$, Lu P, Tang HL, Yan HJ, Jiang $W$, Shi $H$, et al. Valproate induced epigenetic upregulation of hypothalamic fto expression potentially linked with weight gain. Cell Mol Neurobiol 2021;41:1257-69.

4. Dimitrijević A, Stojanović R, Bogićević D, Mitić V, Nikolić DM. Influence of sodium valproate treatment on body mass and insulin resistance parameters in children with epilepsy. Serbian Archives of Medicine 2021;149:53-8.

5. Bai X, Xu C, Wen D, Chen Y, Li H, Wang X, et al. Polymorphisms of peroxisome proliferator-activated receptor $Y$ (PPAR $\gamma$ ) and cluster of differentiation 36 (CD36) associated with valproate-induced obesity in epileptic patients. Psychopharmacology 2018;235:2665-73.

6. Carmona-Vazquez CR, Ruiz-Garcia M, Pena-Landin DM, Diaz-Garcia L, Greenawalt SR. The prevalence of obesity and metabolic syndrome in paediatric patients with epilepsy treated in monotherapy with valproate. Rev Neurol 2015;61:193-201.

7. Rehman T, Sachan D, Chitkara A. Serum insulin and leptin levels in children with epilepsy on valproate-associated obesity. J Pediatr Neurosci 2017;12:135-7.

8. Çiçek NF, Kamaşak T, Serin M, Okten A, Alver A, Cansu A. The effects of valproate and topiramate use on serum insulin, leptin,neuropeptide $Y$ and ghrelin levels in epileptic children. Seizure 2018;58:90-5.

9. Tokgoz H, Aydin K, Oran B, Kiyici A. Plasma leptin, neuropeptide Y, ghrelin, and adiponectin levels and carotid artery intima media thickness in epileptic children treated with valproate. Childs Nerv Syst 2012;28:1049-53. 
10. World Health Organization BMI for age (5-19 years). Erișim tarihi: $25 \mathrm{Kasım}$ 2021. Available from: https://www.who.int/tools/growthreference-data-for-5to19-years/indicators/bmi-for-age

11. Noai M, Soraoka H, Kajiwara A, Tanamachi Y, Oniki K, Nakagawa $\mathrm{K}$, et al. Cytochrome P450 2C19 polymorphisms and valproateinduced weight gain. Acta Neurol Scand. 2016;133:216-23.

12. Matsushita $Y$, Sakai $Y$, Torio $M$, Inoue H, Ochiai M, Yasuoka $K$, et al. Association of perinatal factors of epilepsy in very low birth weight infants, using a nationwide database in Japan. J Perinatol 2019;39:1472-9.

13. Ghosh S, Philip J, Patel N, Munoz-Pareja J, Lopez-Colon D, Bleiweis $\mathrm{M}$, et al. Risk factors for seizures and epilepsy in children with congenital heart disease. JCN 2020;35:442-7.

14. Martin CK, Han H, Anton SD, Greenway FL, Smith SR. Effect of valproate on body weight, food intake, physical activity and hormones: results of a randomized controlled trial. J Psychopharmacol 2009;23:814-25.

15. Pylvanen V, Knip M, Pakarinen, A, Kotila M, Turkka J, Isojarvi JI Serum insulin and leptin levels in valproate-associated obesity. Epilepsia 2002;43:514-17.

16. Luef GJ, Lechleitner M, Bauer G, Trinka E, Hengster P. Valproate modulates islet cell insulin secretion: a possiblemechanism of weight gain in epilepsy patients. Epilepsy Res 2003;5:53-8.

17. Gungor S, Yücel G, Akinci A, Tabel Y, Ozerol $H$, Yologlu S. The role of ghrelin in weight gain and growth in epileptic children using valproate. J Child Neurol 2007;22:1384-8.

18. Masuccio F, Verrotti A, Chiavaroli V, de Giorgis T, Giannini C, Chiarelli $F$, et al. Weight gain and insulin resistance in children treated with valproate: The influence of time. J Child Neurol 2010;25:941-7.
19. Wirrell EC. Valproate-associated weight gain in older children and teens with epilepsy. Pediatr Neurol 2003;28:126-9.

20. Belcastro V, D'Egidio C, Striano P, Verrotti A. Metabolic and endocrine effects of valproicacid chronic treatment. Epilepsy Res 2013;107:1-8.

21. Grosso S, Mostardini R, Piccini B, Balestri P. Body mass index and serum lipid changes during treatment with valproate in children with epilepsy. Ann Pharmacother 2009;43:45-50.

22. Abaci A, Saygi M, Yis U, Demir K, Dirik E, Bober E. Metabolic alterations during valproate treatment: a prospective study. Pediatr Neurol 2009;41:435-9.

23. Verrotti A, Basciani F, Morresi S, de Martino M, Morgese G, Chiarelli F. Serum leptin changes in epileptic patientswho gain weight after therapy with valproate. Neurology 1999;53:230-2.

24. KIIIC H, Demirel A, Uysal S. The effects of valproate on serum leptin, insulin, and lipid levels in epileptic children. Pediatr Int 2021;63:1351-6.

25. Sidhu HS, Srinivas R, Sadhotra A. Evaluate the effects of longterm valproate treatment on metabolicprofiles in newly diagnosed or untreated female epileptic patients: A prospective study. Seizure 2017;48:15-21.

26. Nikolaos T, Stylianos G, Chryssoula N, Irini P, Christos M, Dimitrios T. The effect of long-term antiepileptic treatment on serum cholesterol (TC, HDL, LDL) and triglyceride levels in adult epileptic patients on monotherapy. Med Sci Monit 2004;10:50-2.

27. Chuang YC, Chuang HY, Lin TK, Chang CC, Lu CH, Chang, WN, et al. Effects of long-term antiepilepticdrug monotherapy on vascular risk factors and atherosclerosis. Epilepsia 2012;53:120-8. 